\title{
Free Libraries and the Photographic Survey of Counties."
}

$T^{H}$

HE immense reduction in the cost of photographic apparatus consequent upon the discovery of better and easier methods, has led to a rapid increase in the number of people who choose photography as a recreation-and now, wherever we go, the amateur photographer is either present or very near.

The pursuit is a very pleasant one to those who follow it, and seems to exercise a fascination over its devotees, if we may draw a conclusion from the number of amateurs who attain to excellence.

This spread of photography has been followed, as might bc expected, by the establishment of Photographic Societies in many towns, and I suppose there is hardly a county in England which does not contain one or more Societies.

Several of these Societies are now engaged in making systematic pictorial representations by means of photography of the districts in which they are located; and the object of this paper is to direct the attention of Librarians to the value of these surveys, and to urge the desirability of securing prints from the negatives for preservation in the Public Librarics.

First as to the valuc of the Surveys. This will be best indicated by an outline of the work attempted.

In the photographic survey with which I am most familiar, an attempt is made to secure photographs of all prehistoric, early British, and Roman remains, such as camps, cromlechs, carly crosses, inscribed stones, and Roman roads; of ail buildings or places of interest likely to be removed or altered, the interior and exterior of cathedrals, parish churches, chapels, abbeys, or other ecclesiastical buildings, together with photographs of any spccial features, such as rood screens, carved chests, monuments, and crosses, or any speeial architectural catures; likewise of castles, manor houses, and other dwellings, and the contents of such buildings, such as family portraits or

\footnotetext{
- Real at the Annual Meting of the Library Associatiun held at Notingham, September, ISgi.
} 
portraits of celebrities, old furniture, carvings, documents, \&c. ; views, too, of the coast line, docks, shipping, the streets and principal buildings in towns; and any other objects typical of the county, or associated with local history or the history of the greater world beyond. Particular attention is given to places and objects liable to decay or removal.

(I do not mention the scientific side of the question, such as the photographing of geological strata, boulders, and other phenomena, because in the survey which has come under my notice this is a separate department, under the direction of the Curator of the Museum.)

Secondly: Where should the results be deposited?

The value of such a series of photographs both to the present and future generations will, I think, be at once apparent, and the question arises-How can the work of different photographers be best brought together and be made available for use now, and be at the same time preserved for use in the future? To allow the photographs to remain in the sole possession of those by whom they were taken, to be exchanged about among themselves and their friends, would be to defeat almost entirely the object of the survey. The societies may say, and I believe some societies have said, that the results should belong to the society. But this is not satisfactory, because except by grace of the members the very man who might make important use of the prints might not be able to get access to them, ard unless the society be a very strong one, it will not attract that co-operation from outside plotographers, amatcur and professional, which will be necessary for success.

These remarks point to some public institution, easily accessible, and with a reasonable prospect of permament existence, as the most desirable depository for the results of a Photographic Survey; and if the institution selected possesses an officer who is capable of appreciating, and therefore properly caring for, the prints, so much the better.

All things considered, therefore, I think that the reference department of a free public library is probably the safest and most convenient place for depositing the survey record. The principal library in the district will probably be selected as a central depository, but the other libraries in the county should not be overlooked, and, supposing copies of all the prints cannot be sent to each, then the special pictures relating to the district should be supplied, and also the most important photographs of historical objects and places in the county. 
Thirdly, the method of securing the Survey. If a survey is already in progress the Library Committee or the Town Council night make an application to the society or individuals engaged in its promotion, pointing out the advantages of having a safe and permanent depót. But where a survey is not commenced, the subject should be at once brought to the notice of photographers by the Library Committee or the Librarian, and the importance of the undertaking pointed out. And it will be a good thing, if possible, to secure the interest of some ardent photographer or antiquary who will make the survey a hobby-and determine to carry it out, or at any rate to begin even in the face of discouragements. Every effort should be made to enlist the help of professional photographers and of amateurs who work independently. It is important to hunt up old and forgotten negatives of places perhaps equally forgotten or only dimly remembered, and to get prints from them-if necessary defraying the cost of printing.

After a year or two of work it would be well to try an Exhibition of the results, and perhaps even to offer prizes for the best collections. Here is a schedule of classes from such an. Exhibition :-

I. Gold, silver, and bronze medals respectively for collections of photographs illustrating Glamorganshire, past and present.

One silver and one bronze medal in each of the following classes :

a. Collections illustrating that portion of Monmouthshire (Newport included) within twelve miles of Cardiff.

b. Collections illustrating the churches and chapels of Glamorganshire.

c. Collections illustrating Cardiff, past and present.

d. Collections illustrating Glamorganshire castles, mansions, religious houses, and crosses.

c. Collections of lantern slides, illustrating the County of Glamorgan.

f. Collections of lantern slides, illustrating Cardiff, past and present.

This competition attracted 787 prints, many of them of great excellence, and all of value for the Survey. It has put the Survey work on a sound basis, by showing the importance and interest of the photographic record, by enlisting the in. 
terest of the public, and securing the assistance of many photographers who had hitherto not been attracted; and last, but equally important, by encouraging those already engaged in the work. On all hands surprise has been expressed at the revelation made by the pictures as to the number of places and things of historical interest in the county-and many items unknown or overlooked have been pointed out. The lantern slides were used during the Exhibition for evening demonstrations with limelight, and greatly added to the attractiveness of the Exhibition. They will be available, subject to certain regulations as to security, for lectures and entertainments.

And now a few words as to the arrangement and preservation of the collection.

It is undesirable to have any stipulated size for the prints, but a standard size for the mounts should be adopted, and adhered to as closely as possible. We use 17 in. by 15 in. mounts.

Cards are preferable for mounting, but cartridge paper may be used.

Small prints may be placed two or more on one mount.

Contributors should be allowed to mount their own prints, adhering to the standard mount where possible, or to supply unmounted copies.

The subject, date when taken, and name of the photographer, should be supplied in writing with each print, and notes, such as "removed I8 ", "rebuilt 18 " or other facts, where necessary, should be added.

While not excluding silver prints, an effort should be made to secure all prints in a more permanent process, such as platinotype or carbon.

The collection may be bound either in districts and subdistricts, with special volumes for particular subjects, such as a cathedral. or abbey, or the work of extensive contributors may be kept together, with " miscellaneous " volumes for the smaller contributors, a subject index being provided.

Whichever method be adopted, a copy of the 6in. Ordnance Maps of the County should be obtained, and the objects numbered in red ink, a corresponding number being placed in red on or against the print.

Any printed references to the subjects should be noted either on the mounts or on interleaves, and original information should be carefullv collected and added from time to time. 
Descriptive readings should be prepared to accompany the lantern slides.

Many developments of the value of such a Survey will ensue once the work is fairly in hand. I have brought the subject before you, with a view to encouraging immediate action in the interests of libraries and of historical research.

John Ballinger. 